\title{
Economic Evaluation of the National Program for Community Empowerment on Indonesian Rural Poverty: A Case Study of Aceh Province
}

\author{
Sachnaz Desta Oktarina ${ }^{1 *}$ and Jun Furuya ${ }^{2}$
}

\begin{abstract}
As the largest community-driven development (CDD) program in the globe, National Program for Community Empowerment of Indonesia (PNPM Mandiri) faces a noble target to achieve Sustainable Development Goal (SDG) which is declared in 2015 that formerly named Millennium Development Goal (MDG). In the intervening time, PNPM Mandiri is transformed to newlyestablished institution, Village Law, according to the Law no.6 / 2014. For encountering those challenges policy-makers needs to evaluate their existed development program and re-design the blueprint of present institution to favor the marginalized poor to sustain their economic viability. This article seeks to investigate determinants of village budget allocation of PNPM Mandiri investments from its first earmarked in 2007 and 2011. An evaluation of their return to investment in terms of poverty mitigation within the time frame was also incorporated within the study. It was finally documented that villages-specific endowment prior to PNPM Mandiri establishment were suggested to have reasonable contribution to endogeneity on villagers' decision to select particular allocations. And the allocation of investment were relatively significant to alleviate village's poverty.
\end{abstract}

Keywords: Community-Driven Development Program, Budget Allocation, Poverty, Economic Evaluation

\section{Introduction}

As the Millennium Development Goals (MDG) are expanded to Sustainable Development Goals (SDG), their ambitious objectives remain the same. In the meantime, the National Program for Community Empowerment (PNPM Mandiri) in Indonesia is transformed according to the Law no. 6/ 2014 (ADB, 2016) to newly institution named "Village Law" (dana desa) to ensure a more effective, efficient and neoinstitutional design of community-driven program in Indonesia (ADB, 2016). Given this situation, the 'think tank' or policymaker is prompted to define to what extent the innovation of institution could be induced. In mitigating such challenges, Indonesia needs to critically evaluate its present development program, giving consideration to the international developmental goals while working towards a sustainable re-designing the present institutional blueprint.

Subject to the current setting and the established community-driven mechanism, villagers are able to decide their own preferable investment activities. The driving-force towards village's decision as well as economic evaluation are of particular interest. Considerable attentions to CDD (Community-Driven Development) program has been given to impact evaluation (Oktarina \& Furuya, 2015; Yalegama et al., 2016; Arcand \& Wagner, 2016), elite capture (Dasgupta \& Beard, 2007; Lund \& Jensen, 2013), common-propertyresources (CPR) management (McCarthy et al., 2004), determinant of cooperation, participation and collective action (Beard, 2007; Okten \& Osili, 2004), and critical

${ }^{1}$ University of Tsukuba.

2 Japan International Research Center for Agricultural Sciences.

*Corresponding author 
success factors (Yalegama et al., 2016). However, to evaluate PNPM Mandiri program in terms of return to investment stemmed from agriculture, economic, health, and education sector towards poverty mitigation, which potentially endogenous to villagesspecific characteristics, remains obscured.

Development assistance evaluation of rural agriculture institution intervention has shown progress in some of developing countries. As the instances; Rutherford et al. (2016) and Sahara et al. (2016) suggests that participation in agricultural value chain program contributes to improve living standard in the extent of positive farm outcomes.

Besides agricultural investment, PNPM Mandiri also realized into Economic Investment in terms of woman group of revolving save and loan activities (SPP/ Simpan-Pinjam Perempuan). An efficient financial supports that responds to the needs of the stakeholders enhances economic growth, and creates income-generating activities which is one of the major challenges for under-developed economies (Aliero \& Ibrahim, 2013).

High density of the poor has characterized the group of under developed economies. The poor is mostly prone to negative income shocks due to disasters and health calamities. With the erratic flow of income alongside the risk of outbreaks of epidemics and catastrophic event, the poor's welfare status was exacerbated. Climatic shock i.e drought, flood, and other natural disasters has caused income volatility and negative income shock owing to out-of-pocket spend in schooling and healthcare (Lohmann \& Lechtenfeld, 2015; Mottaleb et al., 2013).

Furthermore, education as precursor of human capital, has shown a significant impact in terms of increasing ability to adapt to new market and innovative requirements, increasing non-agricultural labor supply, and increasing population density on per capita household consumption expenditure (Sahara et al., 2015; Liu \& Yamauchi, 2011).

From aforementioned empirical and theoretical bases, the hypothesis for the study could be examined as three points: firstly, whether PNPM Mandiri investment disbursed in agriculture, economic, education, healthcare activities had negative effect on poverty level of the beneficiaries. Secondly, to test whether the ex-ante village characteristics, such as; number of schools existed in village, number of rural non-farm employment, percentage of household posing access to electricity and percentage of household living in prone-to-disaster areas, contributed to form village resource endowment. Then, as the third hypothesis; this village endowment status gauged as proxy to address impetus of each villages in opting out the budget allocation priorities.

The content of the paper was organized as follows; Section 2 highlights the methodology incorporated into data definition and conceptual framework, Section 3 consists of compiling result and discussion, Section 4 summarizes the important findings into a conclusion and recommendation for further studies.

\section{Data and Methodology}

The research utilized data from Integrated Management Information-Poverty Mitigation BAPPENAS (Simpadu-PK BAPPENAS) for realization of budget allocation data on investment in agriculture, economic, health, and education sector in 2007 and 2011, and national surveys in Indonesia, namely PODES (Village Potential) in 2006 as villages characteristics indicator. The village-wise variables extracted from the data 
sources were consisted of: villages poverty percentage in 2006 and 2011 from PODES survey, as well as village initial characteristics before PNPM Mandiri established which revolved around number of formal schools, number of income-generating activities in rural non-farm employment, percentage of household with access to either public or private electricity, and percentage of household living in prone to disaster area in 2006. Nominal value of PNPM Mandiri budget allocated in agriculture sector, education sector, economic sector, and health sector in 2007 and 2011 was incorporated as the explanatory variables measured by hundred million IDR (Indonesian Rupiah). Table 1 provided the description of each village-wise variables. The village-wise data was selected owing to PNPM Mandiri fashion that primal investment priorities were set initially by the village community as the smallest unit of a decentralized government system. In the local context, the decision making process of the subproject implementation in a village groundwork was designed as a cyclical iterative process. It incorporated village and intervillage meeting to discuss and prioritize development proposal, final funding, program implementation, and evaluation (ADB, 2016). Thus, the process of the decision-making was potentially endogenous. It might be determined by such characteristics that embedded within village society.

In addition, the system of this iterative process would work efficiently conditioned to participatory initiative of the beneficiaries. The contribution of targeted beneficiaries was essential to the extent of best practice of CDD framework. Moreover, according to Okten and Osili (2004), ethnic diversity had a negative effect on both monetary and time contributions as well as on the prevalence of CDD-ground program. From this base of justification, the author motivated to select Aceh province because of its homogeneity in terms of religion and ethnography. It was occupied by more than $98 \%$ Muslim and $70 \%$ Aceh ethnicity. The high degree of homogeneity would benefit the inference process, additionally. As the province received special government system apart from central government, it was assumed that the province conducted specific governance mechanism mutually-exclusive from neighboring province, which was anticipated to control other externalities that might harm reliability of the analysis.

\section{Table 1. Data and Variable Definition}

\begin{tabular}{|c|c|c|c|}
\hline Symbol & Variable & Definition & Unit \\
\hline$y$ & DIFF_POOR & $\begin{array}{l}\text { Difference percentage of Letter of Poor Statement issued in } \\
\text { the village divided by total existing household from } 2006 \text { and } \\
2011\end{array}$ & percent \\
\hline$x_{1}$ & DIFF_HEA & $\begin{array}{l}\text { Difference nominal value of budget allocated in healthcare } \\
\text { activities from } 2007 \text { and } 2011\end{array}$ & 100 million IDR \\
\hline$x_{2}$ & DIFF_EDU & $\begin{array}{l}\text { Difference nominal value of budget allocated in education } \\
\text { activities from } 2007 \text { and } 2011\end{array}$ & 100 million IDR \\
\hline$x_{3}$ & DIFF_ECO & $\begin{array}{l}\text { Difference nominal value of budget allocated in economic } \\
\text { activities from } 2007 \text { and } 2011\end{array}$ & 100 million IDR \\
\hline$x_{4}$ & DIFF_AGR & $\begin{array}{l}\text { Difference nominal value of budget allocated in agriculture } \\
\text { activities from } 2007 \text { and } 2011\end{array}$ & 100 million IDR \\
\hline$x_{5}$ & SCHOOL6 & Number of formal school in 2006 & unit \\
\hline$x_{6}$ & ELECTR6 & Percentage of household having access to electricity in 2006 & percent \\
\hline$x_{7}$ & NONFARM6 & Number of rural non-farm employment in 2006 & unit \\
\hline$x_{8}$ & DISAST6 & Percentage of family live in prone-to-disaster areas in 2006 & percent \\
\hline$\xi$ & $\begin{array}{l}\text { village_ } \\
\text { endowment }\end{array}$ & $\begin{array}{l}\text { Latent variable of village characteristics representing village } \\
\text { resource endowment status }\end{array}$ & not measurable \\
\hline
\end{tabular}


To elaborate association and endogeneity amid a set of variables of interest, the Structural Equation Model was analyzed. The employed model was decomposed simultaneously into following equations:

$$
\left\{\begin{array}{rlrl}
\boldsymbol{y} & =\boldsymbol{\beta}^{\prime} \boldsymbol{x}_{\boldsymbol{i}}+\boldsymbol{\varepsilon} & \\
\boldsymbol{x}_{\boldsymbol{i}} & =\boldsymbol{\Lambda}_{\boldsymbol{i}} \boldsymbol{\xi}+\boldsymbol{\delta}_{\boldsymbol{i}} & ; \mathrm{i}=1,2,3,4 \\
\boldsymbol{x}_{\boldsymbol{j}}=\boldsymbol{\Lambda}_{\boldsymbol{j}} \boldsymbol{\xi}+\boldsymbol{\delta}_{\boldsymbol{j}} & ; \mathrm{j}=5,6,7,8
\end{array}\right.
$$

$y$ was vector of observed difference in poverty rate between 2011 to 2006 measured in village level. $\beta$ was vector of coefficient related to observed exogenous variables $\boldsymbol{x}_{\boldsymbol{i}}$ and observed response variable $y$. the $\boldsymbol{x}_{\boldsymbol{i}}$ comprised village-wise differences in PNPM Mandiri investment between initially earmarked at 2007 and 2011.

The nominal value (in 100 million IDR/ Indonesian Rupiahs) was calculated to a set of agriculture investment, economic investment, education investment and health investment. The remaining observed exogenous variable, $\boldsymbol{x}_{\boldsymbol{j}}$ denoted village initial endowment before PNPM Mandiri establishment in term of; number of schools $\left(\boldsymbol{x}_{\mathbf{5}}\right)$, percentage of household having access to electricity $\left(\boldsymbol{x}_{\mathbf{6}}\right)$, number of rural non-farm employment $\left(\boldsymbol{x}_{\mathbf{7}}\right)$, and percentage of household live in prone to disaster areas $\left(\boldsymbol{x}_{\mathbf{8}}\right)$. Each of observed variables constructed by $\boldsymbol{\xi}$ which explained as unobserved latent variable of village ex-ante resource endowment as a proxy to endogeneity extent of village budget allocations. The factor loading associated with these pathways resembled in vector $\boldsymbol{\Lambda}_{\boldsymbol{i}}$ and $\boldsymbol{\Lambda}_{\boldsymbol{j}}$, respectively. $\boldsymbol{\delta}$ was measurement error for $\boldsymbol{x}$, while $\boldsymbol{\varepsilon}$ was measurement error for $y$ (Bollen, 1989).

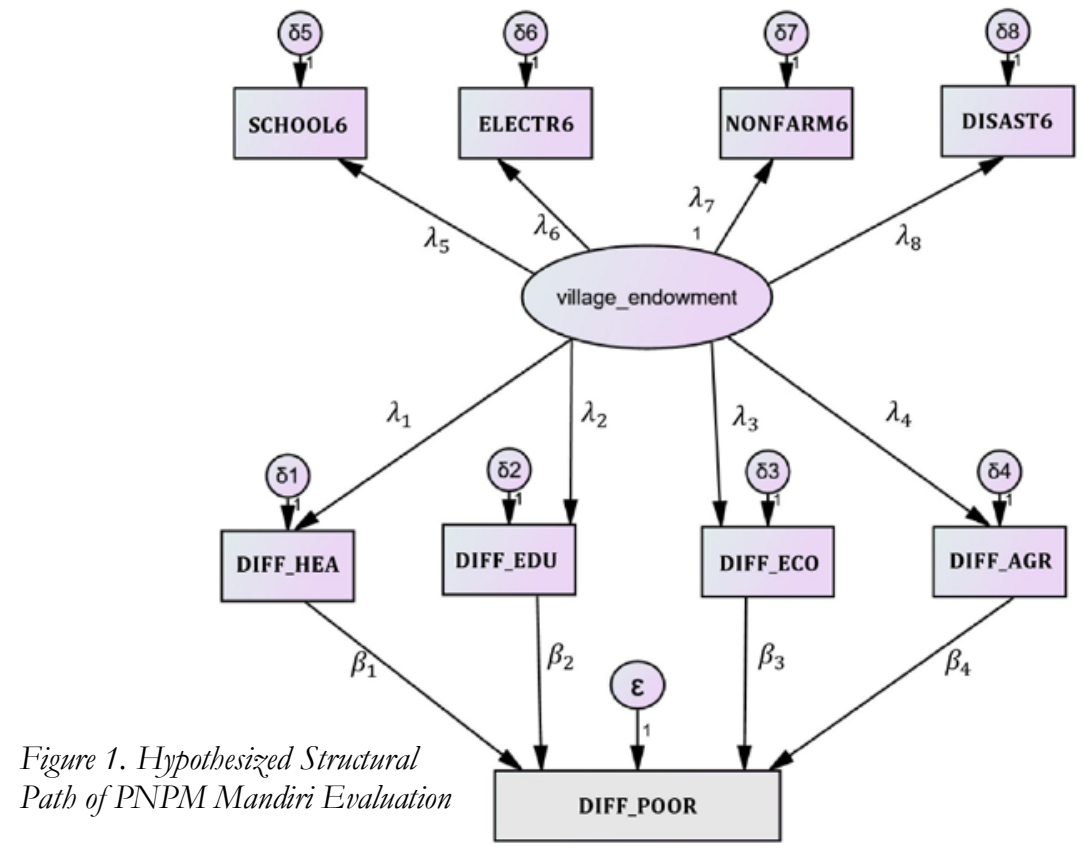


Before applying the regime of the analysis, the data was imputed and checked for validity and reliability. It eventually resulted in 955 villages observations that meet the assumptions of previously mentioned models.

\section{Result and Discussion}

The motivation of constructing the structural equation model or covariance structure analysis, was supported by the versatility of the tools to address causality and confirmatory analysis of latent variables. As the counter-analysis, the instrumental variable which often heavily performed to mitigate omitted variable bias due to measurement error in the analysis, was beyond of this study. This was stemmed from the fact that to find best instrumental variable that has zero covariance with other explanatory and control variables as well as explained variables, was tediously challenging, at least within this sample of observations. The unobserved latent variables inevitably emerged as a proxy to the instrument variables indicating endogeneous regressor of budget allocation investment. Furthermore, it was empirically encouraged by lesson learned from Yalegama et al. (2016) that to find critical determinant in CDD application needed thorough statistical analysis such as structural equation modeling due to subtle portion of inter-correlation between the factors.

On the other hand, Empirical studies suggested the association between disaster, health, and education as indicators of village endowment. Lohmann \& Lechtenfeld (2015) and Mottaleb et al. (2013) has found the evidence from rural Vietnam and Bangladesh case of climatic shock associated with income shock and degradation of human capital. Natural disasters had caused farm household income volatility and negative income shock due to out-of-pocket expense in schooling and healthcare in both of the two study sites. Moreover, in Vietnamese case, it increased the prevalence of illness. Meanwhile, in Bangladesh rural, this income shock was adapted by reducing expenditures on children's education particularly on school admission. These evidences accumulated to lowering human capital as the source of resource endowment in the village domain.

Table 2. Summary of Structure Equation Model

\begin{tabular}{|c|c|c|c|c|c|}
\hline \multicolumn{3}{|c|}{ Path } & \multirow{2}{*}{$\begin{array}{l}\text { Estimate } \\
0.006\end{array}$} & & \multirow{2}{*}{$\frac{\text { S.E. }}{0.009}$} \\
\hline DIFF_HEA & $<---$ & village_endowment & & & \\
\hline DIFF_EDU & $<---$ & village_endowment & -0.014 & & 0.019 \\
\hline DIFF_ECO & $<---$ & village_endowment & 0.058 & $*$ & 0.018 \\
\hline DIFF_AGR & $<---$ & village_endowment & -0.031 & & 0.034 \\
\hline DIFF_POOR & $<---$ & DIFF_HEA & -5.604 & ** & 1.395 \\
\hline DIFF_POOR & $<---$ & DIFF_EDU & -0.851 & & 0.668 \\
\hline DIFF_POOR & $<---$ & DIFF_ECO & -1.128 & & 0.692 \\
\hline DIFF_POOR & $<---$ & DIFF_AGR & -0.255 & & 0.374 \\
\hline SCHOOL6 & $<---$ & village_endowment & 0.638 & $* *$ & 0.090 \\
\hline ELECTR6 & $<---$ & village_endowment & 6.714 & ** & 1.405 \\
\hline NONFARM6 & $<---$ & village_endowment & 10.004 & $* *$ & 1.440 \\
\hline DISAST6 & $<---$ & village_endowment & -3.644 & & 4.374 \\
\hline
\end{tabular}

* denoted significant at alpha 1\%, *** denoted significant at alpha $0.1 \%$ 
In the villages within Aceh Province context, village initial resources endowment was characterized by explanatory variables; number of schools, number of rural non-farm enterprises, percentage of house having electricity facility, and percentage of household live in prone to disaster area in 2006, before PNPM Mandiri was enacted.

These set of village characteristics had reasonably strong inter-covariance, as it was statistically indicated by significant coefficient estimates of village endowment latent variable's component. Based on the summary of analysis provided in Table 2, village endowment positively correlated with village's capacity in terms of number of education facilities, number of rural non-farm employment, and percentage of household having access to electricity. However, this village endowment status had negative correlation with percentage of household living in prone to disaster area. The estimates were all significant at alpha $0.1 \%$ except for the estimates of percentage of household stay in risky areas such as near to riverbanks, prone to soil erosion areas, and slums. These notions were sensible, and theoretically consistent with proceeding evidence.

It was documented that an increase 1 unit of village endowment would increase the number of formal school 0.64 unit, or approximately 1 unit of school at significant level of $0.1 \%$. Subsequently, with the same manner, the percentage of household posing access to electricity was increase $6.7 \%$. And so as number of rural non-farm employment, it would go up by 10 units with the same fashion. The sign condition of percentage of household living in prone to disaster area is satisfactorily, yet the magnitude of estimate was not statistically significant.

In addition, the latent village endowment could work as village welfare status indicated by three manifests (SCHOOL6, NONFARM6, and ELECTR6). If the status of endowment was positive, which meant villages had comparatively adequate resource of school, rural enterprises, and electricity), villagers would tend to vote PNPM Mandiri budget allocation to the investments activities other than the existed one, to sustain and leverage their livelihood. This relationship explained by estimates of factor loading between DIFF_HEA<-village_endowment and DIFF_ECO<-village_endowment, which counted as 0.006 and 0.058 respectively. The interpretation was as followed; the highly-endowed villages (positively correlated with number of school, number of rural economies, and good amenities of electricity) would disburse PNPM Mandiri budget allocation to health and economic investments, as much as respectively $0.006 \times 100$ million IDR $=0.6$ million IDR, and $0.058 \times 100$ million IDR $=5.8$ million IDR higher than poorly-endowed counterparts. The economic investment was crucial for this highlyendowed villages since the rural non-farm employment existed in the village needed financial and credit support to smoothen their business viability (Aliero \& Ibrahim, 2013). This concept consistent with statistical power of the estimates which showed significance at alpha $1 \%$.

Conversely, the poorly-endowed villages which scarce in education institution, rural nonfarm employment, and electrical facility, would select basic investment in education and agricultural sector more than those of highly-endowed villages would allocate. It rose a doubt that the villages condemned as poorly-endowed villages had occupation mostly as rural farmers as their main sustenance. Despite the soundly logical result, the estimates of these parameters were found insignificant. 
The final structural path in Figure 1 (the most-bottom paths) unveiled interesting findings. The sign conditions of each investments were satisfactorily consistent with the literatures in the proceeding section that the increase 100 million IDR in investment in agriculture, education, economy, and health sector would help to decrease poverty with this corresponding scales; $0.3 \%, 0.8 \%, 1.1 \%$, and $5.6 \%$. The highest and most effective estimate was belong to healthcare investment that implied; if 100 million IDR PNPM Mandiri budget allocated to health investment, the poverty rate in the village would decrease as much as 5.6\%. This investment was essential due to the fact that Aceh was the most devastated area hit by Indian Ocean Earthquake and Tsunami back in 2004. It has diminished myriads basic infrastructures as well as human lives there. The healthcare provider was not an exception. The healthcare service in 2006, subsequently, were far from adequate. Therefore, investment in health activities were urgently needed. Otherwise, as Lohmann \& Lechtenfeld (2015) and Mottaleb et al. (2013) suggested, it would perpetuate vicious cycle of poverty in the villages.

Recalling the previous notion that highly-endowed villages prone to allocate more health investment, indicated that villages with higher capacity and endowment would tend to capture the benefit of the PNPM Mandiri budget investment and optimize the allocation to high-yielding investment which was health care investment in the context of rural Aceh Province. In the poorly-endowed villages, it was applied contrary. They were lack in facility of electricity, limited rural non-farm employment, as well as scattered and difficult-to-access school to enjoy decent living standard. This situation became the barriers of villagers to capture the expected benefit of PNPM Mandiri investment.

The overall model adequacy was tested based on Chi-square test which resulted $\chi_{(24)}^{2}=$ 39.043 ( $\mathrm{p}$ value $=0.027$ ), the null hypothesis was not rejected within the alpha $=0.1 \%$. The null hypothesis guaranteed that the data fitted the model well. The other goodness of fits measurements in regard of RMSEA $=0.026$ and CFI $=0.894$ were obtained. The model was said to be fit, if the threshold of RMSEA $<0.05$ and CFI $>0.85$. Aggregately, the author suggested that the data fits the model well and therefore the partial test of individual estimates of structural path in Figure 1 formally reliable to be interpreted.

\section{Conclusion}

The return to investment in PNPM Mandiri has shown effective performance in eliminating poverty in healthcare sector in this case study especially for the investment which satisfactorily significance. There were intrinsic distinguishable preferences of highly-endowed villages and poorly-endowed villages that the richer one would allocate more to health and economic investment, while the poorly-endowed villages would vote for agriculture and education sector. It was suggested that the highly-endowed villages were able to capture expected benefits of investing PNPM Mandiri budget to healthcare facility, and the poorer counterparts were not able to do so. It was arguably documented that the poorer-villages were mostly characterized by farming activity and spatially located in more remote area that access to basic needs was inadequate in there. Thus, further studies elaborating spatial extent would be of future recommendation. 


\section{References}

Aliero, H. M., \& Ibrahim, S. S. (2013) .The Challenges of Youth Empowerment through Access to Credit in the Rural Areas of Nigeria. 2(3), 25-34

Arcand, J. L., Wagner, N. (2016). Does Community-Driven Development Improve Inclusiveness in Peasant Organization?-Evidence from Senegal. World Development, (78), 105-124

Asian Development Bank (ADB). (2016). Toward Mainstreaming and Sustaining Community-Driven Development in Indonesia

Beard, V. A. (2007). Household Contributions to Community Development in Indonesia. World Development, 35(4), 607-625

Bollen, K. A. (1989). Structural Equations with Latent Variables. Wiley series in Probability and Mathematical Statistics. Canada: John Wiley and Sons

Dasgupta, A., \& Beard, V. A. (2007). Community-Driven Development, Collective Action and Elite Capture in Indonesia. Development and Change, 38(2), 229-249

Liu, Y., \& Yamauchi, F. (2014). Population Density, Migration, and Returns to Human Capital and Land: Insights from Indonesia. Food Policy, (48), 182-193

Lohmann, S., \& Lechtenfeld, T. (2015). The Effect of Drought on Health Outcomes and Health Expenditures in Rural Vietnam. World Development, (72), 432-448

Lund, J. F., \& Jensen, M. S. (2013). Revisiting the Issue of Elite Capture of Participatory Initiative. World Development, (46), 104-112

McCarthy, N., Diane, C. D., and Drabo, B. (2004). Cooperation, collective action and Natural Resources management in Burkina Faso. Agricultural System, (82), 233-255

Mottaleb, K. A., Mohanty, S., Hoang, H. T. K., \& Rejesus, R. M. (2013). The Effects of Natural Disasters on Farm Houshold Income and Expenditure: A Study on Rice Farmers in Bangladesh. Agricultural Systems, (121), 43-52

Oktarina, S. D., \& Furuya, J. (2015). The Economic Evaluation of Poverty Alleviation by the National Program for Community Empowerment in Western Part of Rural Indonesia. The Japanese Journal of Rural Economics, (17), 88-91

Okten, C., \& Osili, U. O. (2004). Contribution in heterogeneous communities: Evidence from Indonesia. Journal of population Economics, (17), 603-626

Rutherford, D. D., Burke, H. M., Cheung, K., Field, S. H. (2016). Impact of an Agricultural Value Chain Project on Smallholder Farmers, Households, and Children in Liberia. World Development (83), $70-83$

Sahara, S., Minot, N., Stringer, R., \& J. W. Umberger. (2015). Determinants and Effects of Small Chilli Farmers's Participation in Supermarket Channels in Indonesia. Bulletine of Indonesian Economic Studies, 51(3), 445-60

Yalegama, S., Chileshe, N., Ma, T. (2016). Critical success factors for community-driven development projects: A Sri Lankan community perspective. International Journal of Project Management, (34), 643-659. 